\title{
The Debate Over Euthanasia and Human Rights
}

\author{
Dr. Irena Shala \\ Fakulteti i Shkencave te Natyrës, Universiteti i Shkodrës "Luigj Gurakuqi” \\ Drnt. Kilda Gusha \\ Fakulteti i Psikologjisë, Universiteti i Shkodrës "Luigj Gurakuqi”
}

doi: 10.19044/esj.2016.v12n8p73 URL:http://dx.doi.org/10.19044/esj.2016.v12n8p73

\begin{abstract}
The present article analyzes the debate on issue of euthanasia (voluntary assisted suicide) and the relevance of international human rights norms to that debate. Euthanasia is one of the most complex issues facing human rights, especially given its ethical, legal, medical and religious dimensions. These include: modern medical technology and the availability of medical measures to prolong life; In historical terms inherit challenging laws by refusing euthanasia; The phenomenon of growing older population and the large the number of people affected by AIDS; And fall the impact of religious organizations that consider life to be sacred: terminating a life, for whatever reason, not only infringes religious beliefs but may transgress divine activities beyond the reach of human beings. Justice system is an essential player in the debate. Although euthanasia is generally unlawful, there is an increasing movement towards legalization, particularly in western jurisdictions. Serious political and legal actions taken by euthanasia advocates and their lawyers have brought assisted suicide to the brink of legal assistance. In fact, legislation allowing voluntary euthanasia has been passed in a small number of jurisdictions, and domestic courts in other countries are being repeatedly asked to consider whether the interests at stake with regard to the right to die should be recognized. Die due to euthanasia in Albania is a criminal offense which is considered a violation of the right to live and punished according to the Criminal Code. But in the Code of Ethics and Deontology of the Order of Physicians, there is a provision, which allows the application of a form of interference, which can be interpreted in as passive euthanasia. And this decision remains entirely to the discretion of the physician.
\end{abstract}

Keywords: Mobile phone, mediatization, teen 


\section{Debate on euthanasia}

The issue of euthanasia has gained importance worldwide due to numerous social development and legal. This includes: the development of modern medical technology and artificial excessive length possibility of life; in historical terms we inherit challenging laws by refusing euthanasia; the phenomenon of rising elderly population and the number of people affected by HIV/AIDS; and declining influence of religious organizations. ${ }^{5}$

Besides history, philosophers have often debated the issue when people had the right to give their own life, and in what circumstances would have done. Euthanasia debate has been intense at times, it was justified and the nature of the subject it deals with. It affects essential human interests such as mortality, spirituality and welfare, and therefore provokes deep emotions. Given that most of the constitutional arguments for and against euthanasia are rooted in philosophy, medicine and religion, any discussion of the right to die should look at first, as in every discipline based and in antiquity .

The term euthanasia comes from the Greek word eu which means "good" and thanatos meaning death. The ancient Greeks saw the disease as a boring and suffering ill individuals had the right to seek state approval to commit suicide. ${ }^{6}$ Agreeing with hew, Socrates considered disease agony of pain and suffering as a good reason not to "cling to life." Socrates was not to be an extension of a "no good". Those who are sick in their bodies should be left free to die and corrupt souls and incurable must end their own lives.

Socrates also claimed the life of him to avoid execution after being convicted of committing religious heresy. Although most of the ancient Greek philosophers embraced the practice of euthanasia, suicide of Socrates was not supported enough. Aristotle suicide was an insult to the state, and called this an action against duties as a citizen of a state representative. ${ }^{7}$ Stoic philosophers were the first who accepted suicide perhaps when the disease or deprivation not allowed to live a natural life. After the Roman conquest of Greece, the Stoic philosophy of death dominated the philosophical and legal. Under Roman law, it was acceptable to end a life because of insanity, terminal illness, or fear of a possible dishonor. Suicide is punishable only

\footnotetext{
${ }^{5}$ J Scherer and R Simon Euthanasia and the Right to Die: A Comparative View (Rowman \& Littlefield Publishers, Lanham 1999) 2.

${ }^{6}$ Plato "Phaedo" in Five Great Dialogues 90 (Benjamin Jowett trans, Walter J Black 1942) fq $90-91$

${ }^{7}$ G S Neeley “The Right to SelfDirected Death: Reconsidering an Ancient Proscription” 35 Catholic Law 111 (1995) fq. 116.
} 
when the act is considered irrational. Besides the military criminals and slaves were not allowed to remove life itself. ${ }^{8}$

Stoic views prevailed until century, the influence of Christianity then began to destroy the supporting evidence of suicide, which were seen as inexcusable violation of God's desire. St. Augustine expressed that suicide violated function of church and state, and that was against the Sixth Directive "Do not kill". According to him human suffering decreed by God and human responsibility to keep up this burden.

No matter what disaster befalls an individual or suffering, according to the interpretation of the sacred to St. Augustine this was an irrevocable order: Suicide is never permissible. In the century XIII Christian opposition to euthanasia peaked when Aquini philosopher Thomas (Thomas Aquinas) published a summary of his theological (Summa Theologica). Joining with views of St. That Violate suicide Augustine Sixth Directive Aquinas suicide Presented as illegal and contrary to the Laws of nature and "the worst sin a person Can commit " In the century philosophers began to challenge received opinion of the majority religious about suicide and went to study again the ancient concept of "easy death" (euthanasia) as something that should retry. More Sir. ${ }^{9}$ Thomas, in 1516 wrote "Utopia" which encourage patients living in an ideal society and had terminal disease or incurable pain to commit suicide. ${ }^{10}$

In the early 1900s it was required to regulate and engage in euthanasia legislation, or in some states in the US and the UK, although neither approved. After that, the private society "euthanatize" was created to promote the concept of "mercy killings". However public support to the concept of euthanasia grew during the 1930s and early 1940s, where Nazis adopted this word (euthanasia) to justify "the mass extermination program", relying on that right.

In Nazi Germany, euthanasia embraced the concept of killing 100,000 men, women and children were physical handicapped, mentally disabled or genetically inferior. Nazi idea of euthanasia differed from the idea and historical interpretation as that of today, because of their euthanasia program was never intended to death willingly assistance of a terminally ill patient.

All the killings were done without the consent of patients, as well as the opposition does not take account of the patient in connection with this act. But the damage was already done and considering Nazi Germany, the General Assembly of the World Medical Association adopted a resolution

\footnotetext{
${ }^{8}$ J Scherer and R Simon Euthanasia and the Right to Die: A Comparative View (Rowman \& Littlefield Publishers, Lanham 1999)

${ }^{9}$ New York Task Force, supra note 4, at 80.

${ }^{10}$ Thomas More Utopia, translated by Paul Turner (New York: Penguin, 1981) 102.
} 
urging all national medical associations to condemn euthanasia in any circumstance. $^{11}$

But euthanasia continued to receive more attention and caused more debate. However in the last two decades, the focus of the discussion moved from the political to the legal area, particularly in countries with a tradition of "common law". In addition to a high number of court cases, the "right to die" has challenged legislation that banned euthanasia and asked the panels to define the circumstances in which a patient can receive medical assistance to die. $^{12}$

Draft euthanasia debate widely held in public and its legitimacy was the result of a few countries (distinguishes the Netherlands, Belgium, Northern Territory of Australia (although the government declared invalid law after less than a year after being approved).

However euthanasia debate remains controversial today as in ancient times. Both sides of the argument are determined and clear in their views. It is believed that this dispute will be resolved in a foreseeable future.

\section{The legality and morality of medical assistance to suicide.}

Given the difference in the debate's focus, many commentators have sought to clarify the confusion that has arisen - particularly among people about the meaning of the term. "Euthanasia". Actions refer to the refusal of treatments to keep in life are often called passive euthanasia, while those that have to do with positive acts that cause death are called active euthanasia . Another distinction can be made between euthanasia volunteer, where the consent of the patient is taken to the first, and euthanasia involuntary, where not taken the consent of the patient, for example, when a patient is in a permanent vegetative state or lacks the capacity to consent or permission.

In addition there are suicide with the assistance of a doctor, which involves the use of a deadly substance injected to the patient by him to carry out a suicide less painful. Finally, the doctrine of double effect covers the administration of drugs to relieve pain ill patient suffering despite the knowledge that the doctor that it may have the effect of accelerating the patient's death. Although the law (as will be explained below), reacted differently to different forms of euthanasia, moral arguments pro and against any form are essentially the same. Many opponents continue to rely on the Sixth Directive to support their position against all forms of euthanasia that

\footnotetext{
${ }^{11}$ Ibid, 220.

12 "The Rodriguez Case: Where Do We Go From Here? A MultiDimensional (6layed Approach)”
} 
deem morally wrong. ${ }^{13}$ Others say doctors - who will swear to uphold the Hippocratic Oath and thus are required to care for patients, and not to harm them with the power to "divine" to decide between life and death. They fear that patients may lose confidence in their doctor and euthanasia also may reduce the commitment of doctors to save lives, and may discourage research for new cures and treatments for incurable diseases.Many fear that legalizing euthanasia might lead to a diminished respect for the sanctity of life and the growth of the opinion that some lives (those who have disabilities and are ill) have less value than others. Further concerns arise with regard to the fact that the introduction of a form of euthanasia will lead to other forms less acceptable, where individuals who are thought to have been killed in an unwanted or more binding way. ${ }^{14}$

For example, in the Netherlands there has been movement in recent times to expand the law to allow euthanasia for patients who are not sick, but are "suffering from life" to seek help to end their lives.Taking into account the economic factor, especially taking into account health costs, may lead to health institutions to support euthanasia, especially in cases of ill absolutely hopeless that have no chance of recovery and use better these treatments to patients Medical Ethics with more chances of survival. ${ }^{15}$

Further economic factors may affect the decisions made by patients especially those who do not want to be a burden to their families, or be seen as weak, selfish or irrational and they have become part of the suggestions.At the time when they may be more dependent on their family for emotional support, they can be susceptible to suggestions to end their lives as the best alternative for all the restless, which means they have " liability " to die. On the other hand, supporters of euthanasia base their position on two basic principles: "Mercy" and "Self". 16

They argue that for many individuals, it is important the quality of life, not the sanctity of life or its length. If quality of life is unbearable, because a patient is suffering from unbearable and intolerable pain, the patient should receive mercy from a doctor who directly help to give life. ${ }^{17}$ Most importantly, patients have the right to choose their course of life and it is an "unjustifiable encroachment on individual freedom for preventing a

\footnotetext{
${ }^{13}$ M Otlowski Voluntary Euthanasia and the Common Law (Clarendon Press, Oxford 1997) 213.

${ }^{14} \mathrm{~J}$ Scherer and R Simon Euthanasia and the Right to Die: A Comparative View (Rowman \& Littlefield Publishers, Lanham 1999)

${ }^{15}$ Scherer and Simon, supra note 5, fq 21.

${ }^{16} \mathrm{~J}$ Scherer and R Simon Euthanasia and the Right to Die: A Comparative View (Rowman \& Littlefield Publishers, Lanham 1999)

${ }^{17} \mathrm{~K}$ Amarasekara and M Bagaric The Vacuousness of Rights in the Euthanasia Debate, 6 Int'l J Hum Rgts 19 (2002) fq 21.
} 
terminal patient to seek his desire to end their lives." So patients have the right to seek help from a doctor to abate their life without the possibility of criminal penalties to the doctor's actions. Under Article 167 of the crimes Act 1961, the administration of medication by a doctor who will cover - both forms of active euthanasia (voluntary and involuntary) made with the aim of killing the patient constitutes murder. The fact that a person agrees to his death is not a defense to a murder charge.

Courts have recognized the doctrine of double effect as a defense to criminal charges, but have limited protection for doctors who have expressed the right of intervention to evaluate good or bad effects of deadly pain.

Because euthanasia as murder in Albania constitutes a criminal offense which is considered to violate the right to live and punishable under the Criminal Code. But the Code of ethics and deontology of the Order of Physicians of Albania, there is a provision, which allows the application of some form of intervention (when the man lost consciousness), which can be interpreted in order to expand as passive euthanasia. And this decision is left entirely to the discretion of the physician.

\section{Euthanasia as a human right?}

The ability of patients to choose how they could die should be respected and revered as a way to maintain control, which can help them in maintaining personal dignity in death. In this regard we can mention the case of Rv Martin, where the accused were charged with charges of murdering his mother, who was suffering from an incurable disease (cancer incurable), and in response to this we cannot interfere in the sanctity of life and the patient does not have the legal right to insist to get help to end his life.

Medical training may be rejected by a patient, but the patient may not require medical termination steps through life. However it is possible that in the future there will be times that will seek to challenge the prohibition of criminal law existing in connection with euthanasia because such laws are inconsistent with the rights and freedoms protected in the Charter of Rights, by based on a number of arguments. The right is expressed in the wrong way - is "right not to deprivation of life" rather be "right to life". 18 Although death is inevitable for all the only way for the right to life can be affirmed in stopping wrong deprivation of life. In this regard, it appears that a request for euthanasia would be consistent with the right to life. But it should be argued that the right to life relevant to the protection of a person's right to choose to live or not.

References for this section are taken from the case of Rodriguez $\mathrm{v}$ British Columbia (Prosecutor General). In this case, the Supreme Court of

\footnotetext{
${ }^{18}$ P Rishworth et al The New Zealand Bill of Right (Oxford University Press 2003) fq. 220.
} 
Canada was asked to consider whether the prohibition of assisting in suicide was contrary to the provisions of Canadian and Charter of Rights and Freedoms.Although most judges relied on the constitutional right to reach their decision (judges ruled five to four that the legislation in question did not violate the Canadian Charter). Cory J (dissenting) after making an excuse concluded that the right to die with dignity should be protected like any other aspect of the right to life. ${ }^{19}$ This case is an interesting example of how you can give an interpretation extending the "right to life". But the idea that this right protects not only the "right to life" but also the right to choose not to live is denied by international courts and academics also. ${ }^{20}$

A strong argument in support of euthanasia is that a decision to end life is fundamental to human dignity, personal autonomy and safety, concepts that are protected by various international instruments of human rights.Although the right to liberty and security of person is given a limited interpretation and has so far been limited to freedom from arbitrary detention , the notions of personal autonomy may affect the future development of human jurisprudence around. $^{21}$

Further support for the recognition of human rights and euthanasia may be based on the right to privacy, especially that this right has been used to allow the secession of systems artificial sustain hopeless case involving two patients capable and mentally incapable. E.g. it was suggested that article 8 of the European Convention, which includes the right to respect for private life may be raised as defenses based on the patient's right to seek assistance to die.Indeed, the European Court has recognized that laws preventing patients to exercise their choice to avoid an undignified end to painful life and may constitute an interference with the right to respect for private life. $^{22}$

But the protection offered by this provision is not absolute. The right to privacy under the European Convention was qualified by a provision that approves intervention in this right if it is in accordance with the law and necessary in a democratic society for the protection of health or morals, or the protection of the rights and freedoms of others. Likewise, the provision of the right to privacy in the International Covenant on Civil and Political Rights and is the only protects against "arbitrary or unlawful interference". These qualifications allow judges to consider policy arguments that justify the ban on suicide assistance to doctors. Of particular importance would be if the detention was a necessary and proportionate response to preserve human

\footnotetext{
${ }^{19}$ Ibid, 630, 631.

${ }^{20} \mathrm{~J}$ Scherer and R Simon Euthanasia and the Right to Die: A Comparative View (Rowman \& Littlefield Publishers, Lanham 1999) 2.

${ }^{21}$ Rishworth, supra note 41, fq 236.

${ }^{22}$ Pretty, supra note 45 , fq 67.
} 
life and protection against abuse. The European Court noted in the case Pretty: "The forecast of the law in this case is designed to protect human life, protecting the weak and vulnerable, especially those who are unable to make informed decisions against acts intended to the end of live , or help in ending the life.

"Another argument likely to support the individual's right to seek assistance to die may be based on Article 19 of the Convention, which provides the right to freedom from discrimination on the basis determined in section 21 of the Act Human Rights of 1993. These grounds include disability, which covers physical disabilities and mental. It is possible to argue that the prohibition on assistance for suicide doctor, violates the right to non-discrimination of patient. ${ }^{23}$

While the argument that was also raised in the Pretty case, the European Court held that any discrimination arising justified because the state has a duty to regulate through the operation of the general criminal law activities which are detrimental to the life and safety of other individuals .

According to the court building a law that protects those who seek assistance to die, it will seriously affect the protection of life and increase the risk of abuse. An argument, though not widespread, can be based on the right of thought, conscience, religion and belief, which is protected by section 13 of the Convention Europe. ${ }^{24}$

An even less plausible argument that the prohibition of euthanasia is limiting the patient's right not to be subjected to cruel and degrading treatment. Stress, pain and suffering of a terminally ill or degrading treatment represents, and, although not directly responsible, the state is obliged to protect its citizens from such treatments. From this discussion, it is clear that a number of arguments can be made in support of the view that euthanasia should be recognized as a right. However, in the absence of any law to support, it is doubtful that such recognition will be granted on the basis of the Charter of Rights or other instruments of human rights

\section{Conclusion}

Although euthanasia is illegal, there is a growing movement toward legalization, especially in overseas jurisdictions. In fact, although legislation allowing euthanasia voluntarily move to a small number of countries, domestic courts in other countries, but the European Court is being asked repeatedly to review whether the interests at stake in relation to the right to die should be recognized. Based on the experience of the general human

\footnotetext{
${ }^{23} R$ (on the Application of Dianne Pretty) $v$ DPP and Secretary of State for the Home Department [2002] 1 All ER 1.

${ }^{24}$ Pretty, supra note 50, fq. 89.
} 
rights will continue to play an important role in the euthanasia debate. Although the rights and freedoms protected in the Charter of Rights does not recognize the "right to die" (euthanasia), they do not seem to hinder euthanasia voluntary until appropriate measures procedural protection have been introduced in each regime allowing patients seeking help to die .

But human rights will not give an answer to many of the concerns that have been raised in connection with euthanasia, particularly with regard to possible abuses by doctors and medical institutions, family members of patients and society in general. It also will not solve the fight between various religious doctrines, social and philosophical positions regarding "value and meaning of life, spending the virtues and moral suffering and social taboos against the act of suicide". Unfortunately not seen to have any answers to these simple silence.

\section{References:}

Dr A Brown “What Can We Learn From the Pretty Cases?” Human Rights \& UKP 3.3(8) (2002).

E Gifford "Artes Moriendi: Active Euthanasia and the Art of Dying” 40 UCLA l Rev 1545 (1993).

F Pakes "Under Seige: The Global Fate of Euthanasia and AssistedSuicide Legislation” 13 Eur J Crime, Cr

J Scherer and R Simon Euthanasia and the Right to Die: A Comparative View (Rowman \& Littlefield Publishers, Lanham 1999)

K Amarasekara and M Bagaric The Vacuousness of Rights in the Euthanasia Debate, 6 Int'l J Hum Rgts 19 (2002) L \& Cr J 119 (2005).

L Bradbury "Euthanasia in the Netherlands: Recognising Mature Minors in Euthanasia Legislation” 9 New Eng J Int'l \& Comp L 209 (2002).

M Otlowski Voluntary Euthanasia and the Common Law (Clarendon Press,Oxford 1997)

$\mathrm{P}$ van Dijk and G J H van Hoof Theory and Practice of the European Convention on Human Rights (3rd ed 1998)

Plato “Phaedo" in Five Great Dialogues 90 (Benjamin Jowett trans, Walter J Black 1942)

Sharpe, K Swinton and K Roach The Charter of Rights and Freedoms (2 nd ed) (Irwin Law: Canada 2002).

W J Smith Forced Exit: The Slippery Slope from Assisted Suicide to Legalised Murder (1997) 115, quoted in J Nugent "Walking into the Sea" of Legal Fiction: An Examination of the European Court of Human Rights, Pretty v United Kingdom and the Universal Right to Die”. 